\title{
Polymerized Luteolin Nanoparticles: Synthesis, Structure Elucidation, and Anti-Inflammatory Activity
}

\author{
Parichat Tawornchat, Thitiporn Pattarakankul, Tanapat Palaga, Varol Intasanta, \\ and Supason Wanichwecharungruang*
}

Cite This: ACS Omega 2021, 6, 2846-2855

Read Online

ABSTRACT: Luteolin is an anti-inflammatory flavonoid commonly found in many edible plants. The compound is popularly consumed as a supplement regardless of its poor water solubility $\left(27.8 \mu \mathrm{g} / \mathrm{mL}\right.$ at $\left.25^{\circ} \mathrm{C}\right)$ and low bioavailability. Here, mild one-pot polymerization of luteolin into water-dispersible nanospheres, with an average dry size of $234.8 \pm 101.6 \mathrm{~nm}$, an aqueous size distribution of $379.1 \pm 220.5 \mathrm{~nm}(\mathrm{PDI}=0.338)$, an average $\zeta$ potential of $-36.2 \pm 0.2 \mathrm{mV}$, and an $89.3 \pm 4.8 \%$ yield, is described. The nanospheres consist of polymerized luteolin (polyluteolin) with a weight-average molecular mass of around $410000 \mathrm{Da}$. The chemical structure of polyluteolin is identified through ${ }^{1} \mathrm{H}-{ }^{1} \mathrm{H}$ correlated spectroscopy (COSY), ${ }^{1} \mathrm{H}-{ }^{13} \mathrm{C}$

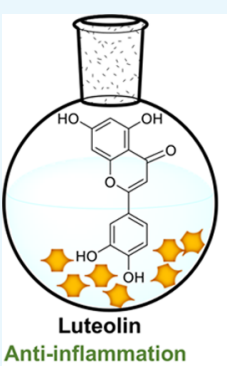

Cytotoxic

Precipitate in water

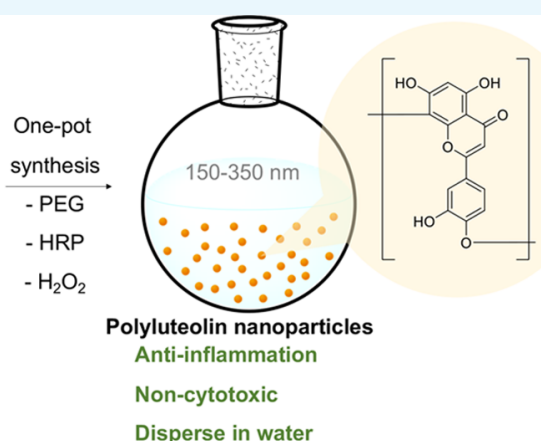
heteronuclear single-quantum coherence (HSQC), and ${ }^{1} \mathrm{H}-{ }^{13} \mathrm{C}$ heteronuclear multiple-bond correlation (HMBC) NMR spectroscopic analyses of the oligomers, and a polymerization mechanism is proposed. Unlike luteolin that showed both dosedependent anti-inflammatory activity and cytotoxicity when tested in lipopolysaccharide-stimulated macrophages, the polyluteolin nanoparticles possess dose-dependent anti-inflammatory activity without causing cell death even at high concentrations.

\section{INTRODUCTION}

Inflammation is an immune response that the body produces to inhibit infection and heal the damaged tissue. However, chronic inflammation can develop into diseases such as arthritis, chronic obstructive pulmonary disease, and cancer. ${ }^{1-3}$ Fruits and vegetables contain secondary metabolites that possess anti-inflammatory activities; therefore, consuming enough of them can reduce the risk of those diseases. ${ }^{4-6}$

Researchers from various places have reported that luteolin $\left(3^{\prime}, 4^{\prime}, 5,7\right.$-tetrahydroxyflavone), a flavonoid found in many fruits, vegetables, and medicinal plants including onion leaves, celery, broccoli, and carrot (luteolin contents of 391.0, 80.5, 74.5 , and $37.5 \mathrm{mg} / \mathrm{kg}$ of dry weight, respectively), ${ }^{7}$ possesses strong anti-inflammatory activity. ${ }^{8-11}$ Although the compound has been sold as a health supplement or part of health supplement formulations for various claims, the low bioavailability of this compound has been reported. A pharmacokinetic study on oral administration of extracts containing luteolin in beagle dogs at $7.6 \mathrm{mg} / \mathrm{kg}$ showed a peak concentration of luteolin in plasma $\left(C_{\max }\right)$ of $0.6 \mu \mathrm{g} / \mathrm{mL}$ and the total luteolin in plasma (area of luteolin concentration peak over time or $\mathrm{AUC}_{0 \rightarrow \infty}$ ) of $6.3 \mu \mathrm{g} \mathrm{h} / \mathrm{mL}$. The report agrees with the low luteolin absorption in mini-pigs (luteolin dose of $6.8 \mathrm{mg} / \mathrm{kg}$, $C_{\max }$ of $0.5 \mu \mathrm{g} / \mathrm{mL}$, and $\mathrm{AUC}_{0 \rightarrow \infty}$ of $4.9 \mu \mathrm{g} \mathrm{h} / \mathrm{mL}$ ) and humans (luteolin dose of $1.5 \mathrm{mg} / \mathrm{kg}, C_{\max }$ of $0.3 \mu \mathrm{g} / \mathrm{mL}$, and $\mathrm{AUC}_{0 \rightarrow \infty}$ of $2.0 \mu \mathrm{g} \mathrm{h} / \mathrm{mL}) .{ }^{12}$ Improvement of luteolin bioavailability could be achieved using nanostructured lipid carriers (NLCs) and microemulsions (MEs). When rats were given luteolin at a dose of $3.5 \mathrm{mg} / \mathrm{kg}$, the $C_{\max }$ changed from $0.6 \mu \mathrm{g} / \mathrm{mL}$ for the original luteolin to $0.5 \mu \mathrm{g} / \mathrm{mL}$ for luteolin in NLC and $1.6 \mu \mathrm{g} /$ $\mathrm{mL}$ for luteolin in $\mathrm{ME}$, and the $\mathrm{AUC}_{0 \rightarrow \infty}$ increased from $1.2 \mu \mathrm{g}$ $\mathrm{h} / \mathrm{mL}$ for the original luteolin to $10.7 \mu \mathrm{g} \mathrm{h} / \mathrm{mL}$ luteolin in NLC and $16.2 \mu \mathrm{g} \mathrm{h} / \mathrm{mL}$ for luteolin in ME. Nevertheless, the luteolin loading content in both the NLC and ME was only $0.15 \%$, meaning that large amounts of auxiliary materials were administered to animals when NLC or ME was used to deliver luteolin. $^{13}$

Another approach to solving the low-bioavailability problem is by encapsulating luteolin into various polymeric particles. Researchers have reported the use of methoxy poly(ethylene glycol) (PEG)-polylactide-co-glycolide, methoxy poly(ethylene glycol)-polylactide, methoxy poly(ethylene glycol)-polycaprolactone, and polylactic acid-poly(ethylene glycol) ether for the encapsulation of luteolin. ${ }^{14-16}$ These encapsulations have resulted in aqueous formulations of

Received: October 22, 2020

Accepted: January 6, 2021

Published: January 19, 2021 

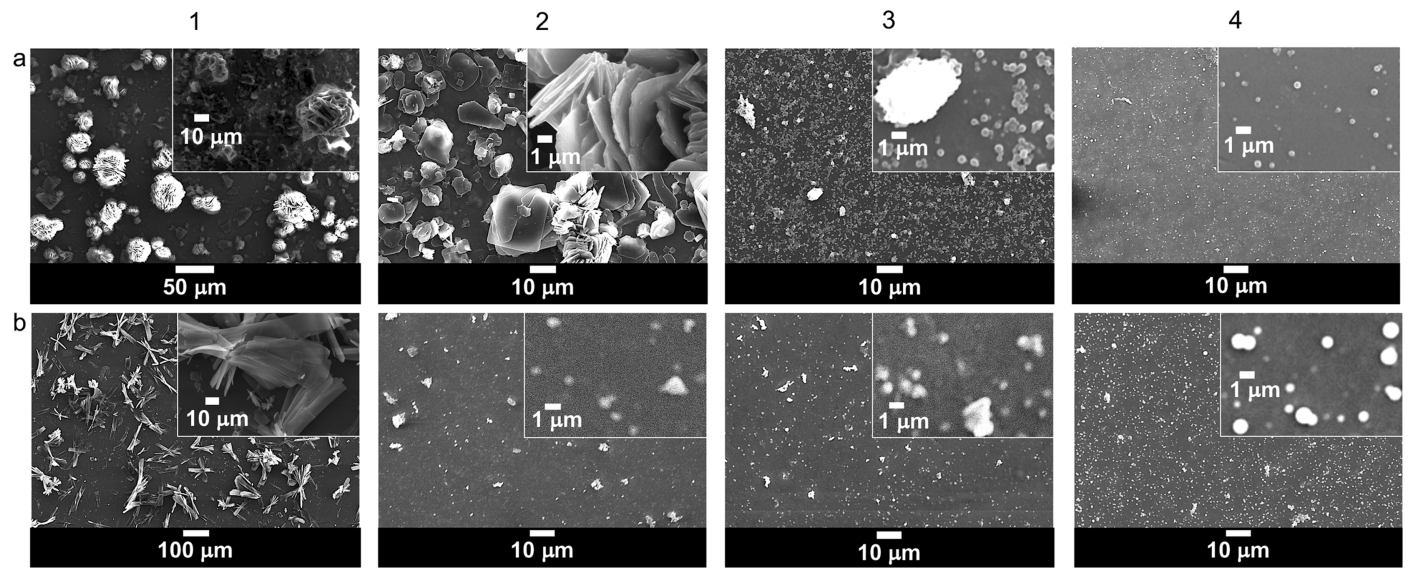

Figure 1. Scanning electron microscopy (SEM) images of luteolin (1a) and products prepared under different reaction conditions (2a-4b). Reaction conditions are denoted in parentheses. (2a) Product 1 (no HRP $\left|\mathrm{H}_{2} \mathrm{O}_{2}\right| \mathrm{PEG} 2050$ ), (3a) Product $2\left(1.7 \% \mathrm{HRP}\left|\mathrm{H}_{2} \mathrm{O}_{2}\right| \mathrm{PEG} 2050\right.$ ), (4a) Product 3 (3.3\% HRP | $\mathrm{H}_{2} \mathrm{O}_{2} \mid$ PEG 2050), (1b) Product 4 (3.3\% HRP | no $\mathrm{H}_{2} \mathrm{O}_{2} \mid$ PEG 2050), (2b) Product $5\left(3.3 \% \mathrm{HRP}\right.$ 等 $\mathrm{O}_{2} \mid$ no PEG), (3b) Product 6 (3.3\% HRP | $\mathrm{H}_{2} \mathrm{O}_{2} \mid$ PEG 200), and (4b) Product 7 (3.3\% $\mathrm{HRP}\left|\mathrm{H}_{2} \mathrm{O}_{2}\right|$ PEG 35000).

luteolin with better biological activity. Nevertheless, less than $4.0 \%$ of luteolin loading content could be achieved; therefore, large amounts of auxiliary polymeric materials are parts of formulations.

Autopolymerization of flavonoid compounds in harvested plants have been extensively studied. ${ }^{17,18}$ Improved anticancer and antihypertriglyceridemia activities were observed for the small oligomeric products such as theasinensin, theaflavin, thearubigin, and procyanidin, obtained from natural catechin polymerization, which automatically takes place in tea leaves during storage and fermentation. ${ }^{19-22}$ Some of the studies on natural autopolymerization of flavonoids indicated that only water and heat are needed to allow the reaction to take place in situ. $^{23,24}$ However, some reports stated the importance of oxidative enzymes such as polyphenol oxidase (PPO), peroxidase (POD), and catalase, of which PPO was reported as the most important oxidative enzyme in polymerization of polyphenols in tea leaves. ${ }^{25-31}$ These reports inspired us to explore the possibility to polymerize other plant extracts that possess chemical structures related to catechin.

Here, we show one-pot synthesis of water-dispersible polyluteolin nanoparticles from luteolin via an enzymatic template polymerization using hydrogen peroxide as a reagent, PPO as a catalyst, and poly(ethylene glycol) polymer (PEG) as a template. In addition to reaction optimization, this work also involves product characterizations regarding chemical structure, morphology, anti-inflammatory activity, and cytotoxicity.

\section{RESULTS AND DISCUSSION}

Natural fermentation of catechin can take place with the peroxidase enzyme present naturally in tea leaves and oxygen in the atmosphere. ${ }^{32,33}$ Because of the related chemical structure between luteolin and catechin, here, we have explored the possibility to polymerize luteolin by mimicking the natural environment in tea leaves. We explored the roles of oxidative enzyme horseradish peroxidase (HRP), oxidizing agent $\mathrm{H}_{2} \mathrm{O}_{2}$, and the PEG template. The biocompatible and bioinert PEG template was used to mimic macromolecular substrates in tea leaves, which may act as seeds or templates of the polymerization reaction.

During one-pot synthesis of polyluteolin, it was noticed that with not enough HRP in the reaction mixture (Table 2,
Products 1 and 2), there was no chemical transformation. The NMR, IR, and UV spectra of Products 1 and 2 (Figures 2 and S1 and S2 in the Supporting Information, SI) are similar to those of the starting luteolin. This information suggests that the obtained Products 1 and 2, which appeared as waterinsoluble precipitates, are luteolin aggregates (Figures 1, 2a, and $3 \mathrm{a})$. When the amount of HRP was increased to $3.3 \%$

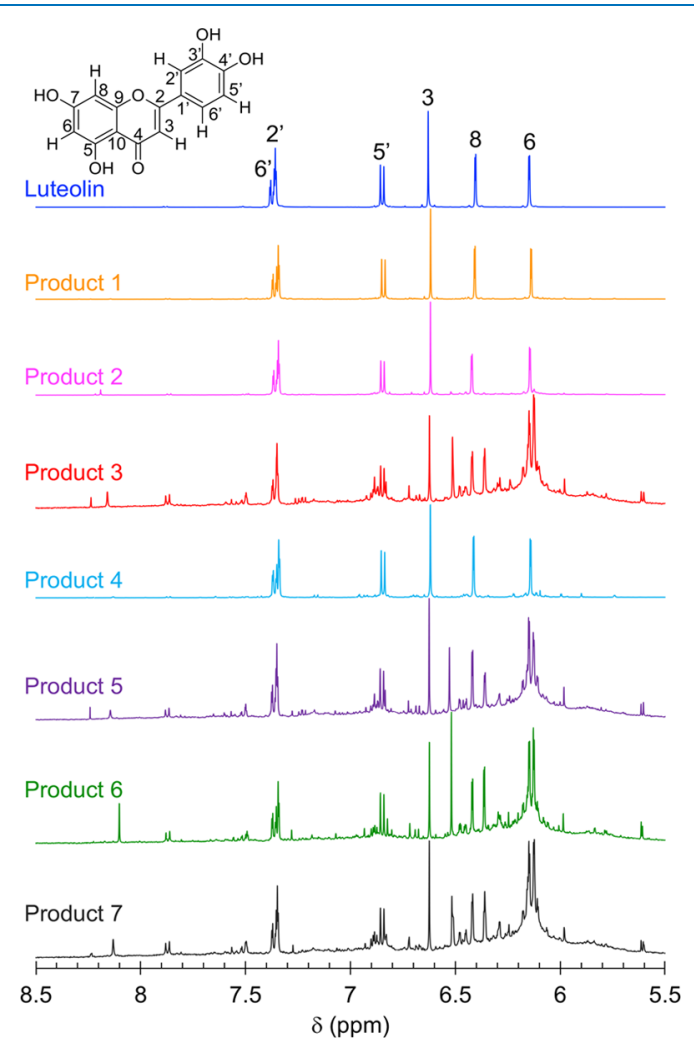

Figure 2. ${ }^{1} \mathrm{H}$ NMR $\left(20 \mathrm{mg} / \mathrm{mL}\right.$, DMSO- $\left.d_{6}, 500 \mathrm{MHz}\right)$ spectra of luteolin and products prepared under different conditions: no HRP I $\mathrm{H}_{2} \mathrm{O}_{2}$ | PEG 2050 (Product 1), 1.7\% HRP | $\mathrm{H}_{2} \mathrm{O}_{2}$ | PEG 2050 (Product 2), 3.3\% HRP | $\mathrm{H}_{2} \mathrm{O}_{2} \mid$ PEG 2050 (Product 3), 3.3\% HRP । no $\mathrm{H}_{2} \mathrm{O}_{2} \mid$ PEG 2050 (Product 4), 3.3\% HRP | $\mathrm{H}_{2} \mathrm{O}_{2} \mid$ no PEG (Product 5), 3.3\% HRP | $\mathrm{H}_{2} \mathrm{O}_{2} \mid$ PEG 200 (Product 6), and 3.3\% HRP I $\mathrm{H}_{2} \mathrm{O}_{2} \mid$ PEG 35000 (Product 7). 


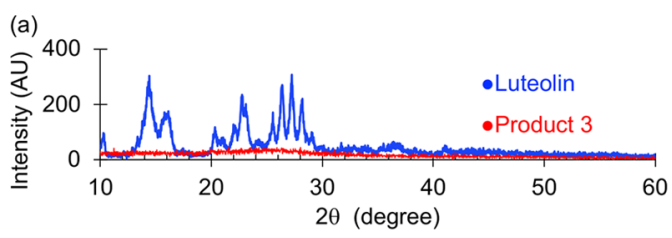

(b) Standard curve $\left(R^{2}=0.9994\right)$

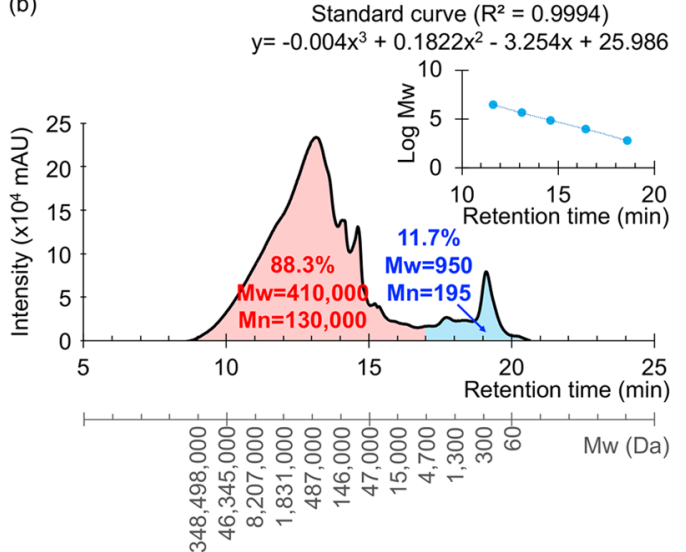

Figure 3. (a) X-ray diffraction (XRD) patterns of luteolin and polyluteolin nanoparticles (Product 3) and (b) gel filtration chromatography (GFC) chromatogram $(10 \mathrm{mg} / \mathrm{mL}, N, N$-dimethylformamide (DMF); PDA detector at $254 \mathrm{~nm}$ ) of polyluteolin (Product 3). Polystyrene $\left(M_{\mathrm{p}}=580,9820,67600,466300\right.$, and $3152000 \mathrm{Da})$ standard curve is shown in the upper left.

(Table 2, Product 3), water-dispersible nanoparticles with an average dry size of $234.8 \pm 101.6 \mathrm{~nm}$ (Figures 1 and $4 \mathrm{a}$ ) were obtained. Product 3 possesses significant differences in the NMR, IR, and UV spectra from those of luteolin (Figures 2 and $S 1$ and $S 2$ in the SI). The IR spectrum of Product 3 (Figure $\mathrm{S} 1$ in $\mathrm{SI}$ ) possesses a broader $\mathrm{O}-\mathrm{H}$ stretching vibration (at $3265 \mathrm{~cm}^{-1}$ ) than that of luteolin (at 3417 $\mathrm{cm}^{-1}$ ). The $\mathrm{C}=\mathrm{C}$ stretching vibration of luteolin appears as triple peaks at 1606,1574 , and $1500 \mathrm{~cm}^{-1}$, whereas that of Product 3 appears as a broad peak with maxima at 1612 and $1504 \mathrm{~cm}^{-1}$. The phenolic $\mathrm{C}-\mathrm{O}$ stretching vibration of luteolin appears as triple peaks at 1365,1263 , and $1246 \mathrm{~cm}^{-1}$ whereas that of Product 3 appears as a broad peak with maxima at 1354 and $1257 \mathrm{~cm}^{-1}$. These changes correspond well with the speculative polymer structure of Product 3 , in which the broad peaks are caused by overlapping of many slightly different frequencies of vibration resulted from geometrical irregularities and different physical environments among various connected units. Additionally, the UV absorption band of luteolin in dimethyl sulfoxide (DMSO) appears at $\lambda_{\max }$ values of 271 and $353 \mathrm{~nm}\left(\pi-\pi^{*}\right.$ transition of benzoyl system and $\mathrm{n}-\pi^{*}$ transition of cinnamoyl system, respectively), whereas that of Product 3 shows a broader absorption band with more absorption at a longer wavelength, indicating the increased conjugation of Product 3 as compared to the conjugation system in luteolin.

It was observed through the SEM images that the reaction performed without $\mathrm{H}_{2} \mathrm{O}_{2}$ (Table 2, Product 4) gave a product with similar morphology to the luteolin morphology (Figure 1b). The NMR and UV spectra of Product 4 (Figures 2 and S2 in the SI) are also similar to those of luteolin, indicating that the chemical transformation did not take place.

Next, the effect of molecular mass of PEG on product formation was investigated. Replacing PEG 2050 (Table 2, Product 3) with PEG 200 and PEG 35000 (Table 2, Products 6 and 7), also a reaction without PEG (Table 2, Product 5), still gave obvious chemical transformation of luteolin. The NMR, IR, and UV spectra of Products 5-7 are different from those of luteolin but similar to those of Product 3, indicating that similar polymerization reactions were taking place under these conditions. The molecular mass of PEG or the absence of PEG did not affect the chemical transformation of luteolin but rather affected the morphology of the obtained polymerized products. Product 3 (obtained with PEG 2050) is uniform spherical particles of 200-300 nm diameter, and Products 5 (obtained with no PEG) and 6 (obtained with PEG 200) are spherical particles of similar size with some obvious big aggregates (Figures 1, 2b, and $3 \mathrm{~b}$ ). A product with a bigger particle size (average dry size of $857.8 \pm 235.1 \mathrm{~nm}$ ) was observed when PEG 35000 was used (Product 7, Figures 1 and 4b).

With our goal of making water-dispersible nanoparticles for water-based formulations that could target inflammation, the morphology of Product 7 was considered too big. This is because a previous study has shown that only nanoparticles in

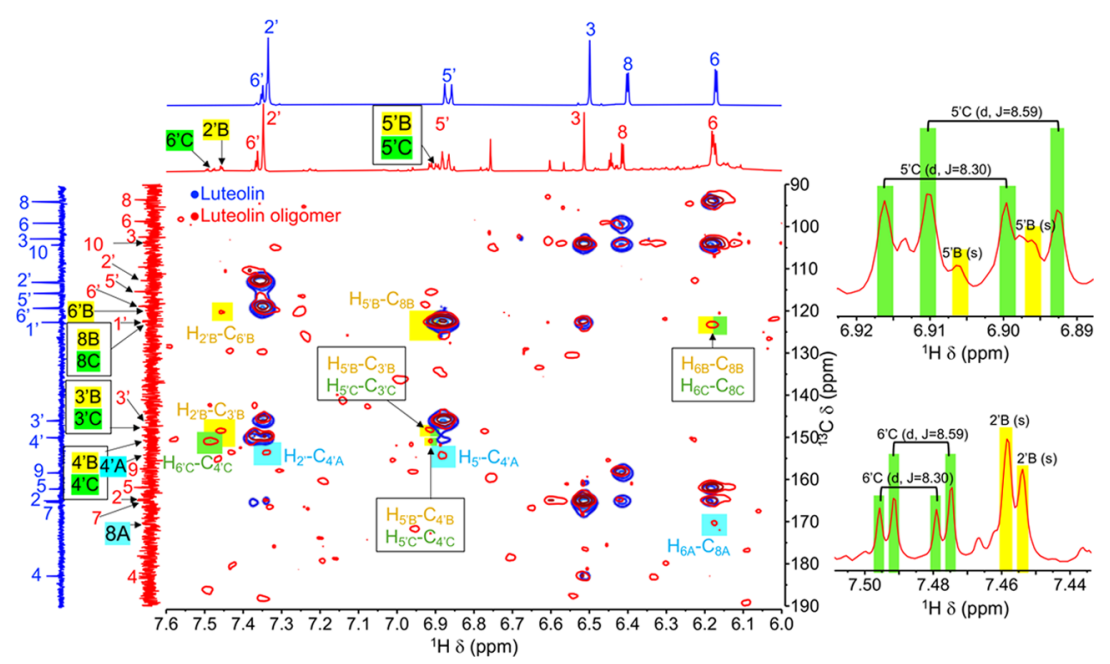

Figure 4. Overlay of ${ }^{1} \mathrm{H}-{ }^{13} \mathrm{C}$ heteronuclear multiple-bond correlation (HMBC) NMR correlations (MeOD- $d_{4}, 500 \mathrm{MHz}$ ) of luteolin and luteolin oligomers. 
Table 1. ${ }^{1} \mathrm{H}$ and ${ }^{13} \mathrm{C}$ NMR Chemical Shift of Luteolin and Luteolin Oligomer I (MeOD- $d_{4}, 500 \mathrm{MHz}$ )

\begin{tabular}{|c|c|c|c|c|}
\hline \multirow[b]{2}{*}{ Position } & \multicolumn{2}{|c|}{ Luteolin } & \multicolumn{2}{|c|}{ Luteolin oligomer I (major product) } \\
\hline & ${ }^{1} \mathrm{H} \delta(\mathrm{ppm}), J(\mathrm{~Hz})$ & ${ }^{13} \mathrm{C} \delta(\mathrm{ppm})$ & ${ }^{1} \mathrm{H} \delta(\mathrm{ppm}), J(\mathrm{~Hz})$ & ${ }^{13} \mathrm{C} \delta(\mathrm{ppm})$ \\
\hline 2 & & 164.63 & & 164.61 \\
\hline 3 & $6.51(1 \mathrm{H}, \mathrm{s})$ & 102.53 & $6.51(1 \mathrm{H}, \mathrm{s})$ & 102.50 \\
\hline 4 & & 182.49 & & 182.23 \\
\hline 5 & & 161.84 & & 161.94 \\
\hline 6 & $6.18(1 \mathrm{H}, \mathrm{d}, 2.3)$ & 98.77 & $6.17(1 \mathrm{H}, \mathrm{m})$ & 98.74 \\
\hline 7 & & 164.96 & & 165.01 \\
\hline 8 & $6.41(1 \mathrm{H}, \mathrm{d}, 2.3)$ & 93.66 & $6.41(1 \mathrm{H}, \mathrm{d}, 2.3)$ & 93.60 \\
\hline $8 \mathrm{~A}$ & & & & 177.03 \\
\hline 9 & & 158.05 & & 157.40 \\
\hline 10 & & 103.97 & & 103.66 \\
\hline $1^{\prime}$ & & 122.36 & & 122.40 \\
\hline $2^{\prime}$ & $7.35(1 \mathrm{H}, \mathrm{m})$ & 112.85 & $7.35(1 \mathrm{H}, \mathrm{m})$ & 112.73 \\
\hline $3^{\prime}$ & & 145.69 & & 145.85 \\
\hline $4^{\prime}$ & & 149.65 & & 149.65 \\
\hline $4^{\prime} \mathrm{A}$ & & & & 154.38 \\
\hline $5^{\prime}$ & $6.88(1 \mathrm{H}, \mathrm{dd}, 8.9,2.0)$ & 115.45 & $6.87(1 \mathrm{H}, \mathrm{dd}, 8.9,2.0)$ & 115.38 \\
\hline $6^{\prime}$ & $7.36(1 \mathrm{H}, \mathrm{m})$ & 118.99 & $7.36(1 \mathrm{H}, \mathrm{m})$ & 118.81 \\
\hline
\end{tabular}

the size range of $10-500 \mathrm{~nm}$ can leave the blood vessel and accumulate inside the inflamed tissue. ${ }^{34}$ Due to the small uniform size of Product 3, this product was selected for further characterization and evaluation of anti-inflammatory activity.

It should be noted here that the first intention of using PEG in the reaction was for the material to act as a template for polymerization. ${ }^{35}$ Nevertheless, the observation that polymerization could take place with no PEG (Product 5) suggests a different role of PEG. It should be noticed here that for all reactions that contained PEG (Product 1-4, 6 and 7), the amount of PEG added to the reaction was at $10 \%$ relative to the amount of luteolin. We observed that PEG plays a crucial role in particle formation of the polymerized products, e.g., uniformed particles could not be obtained without PEG (Product 5). We speculate that PEG acts as a corona of the self-assembled particles, making the obtained polymerized particles water-dispersible and nonaggregated. Without PEG, big aggregates were observed (Product 5). With too large PEG molecules $(35000 \mathrm{Da})$, big aggregated particles were observed (Product 7). By fixing the $10 \%$ weight of PEG used in the reaction but increasing the molecular weight of the material, the numbers of PEG chains present in the reaction automatically decreased. It was likely that in the case of PEG 35000, there were not enough PEG molecules to surround each smaller particle; therefore, aggregation into bigger particles took place. In contrast, there were higher numbers of PEG chains to surround smaller polyluteolin particles when smaller PEG molecules (2050 Da) were used. As a result, uniform 200-300 nm polyluteolin particles were obtained from the reaction using PEG 2050 (Product 3). Nevertheless, with too small PEG (200 Da), the PEG corona was probably not long enough to prevent the aggregation of the particles; thus, aggregated particles were produced when PEG 200 was used (Product 6).

In aqueous, more than $90 \%$ of Product 3 accounts for the particles with an average diameter of $379.1 \pm 220.5 \mathrm{~nm}$ (PDI = 0.338 , Figure S3 in the SI). The high S.D. value indicates broad size distribution and corresponds well with the depicted size distribution curve (Figure S3). The broad size distribution of Product 3 might stem from the self-assembling process that took place in tandem to the growth of Product 3 chains. With an abundance of PEG in the system at the beginning of synthesis, there would be enough PEG to cover the surface of small particles. Later, with less amount of PEG, the particle size had to increase so that the particle surface would have PEG to cover. This resulted in the formation of small to large particles. It should be noted here that we limited the amount of PEG in the system based on our intention to prepare particles of polyluteolin with a minimal amount of auxiliary material.

The obtained product 3 gave a PDI of 0.338 , corresponding well to the unimodal size distribution (one maximum) of the particles (Figure S3). The high negative $\zeta$-potential of $-36.2 \pm$ $0.2 \mathrm{mV}$ agrees with the observation that the aqueous suspension of Product 3 is stable, i.e., no precipitation or sedimentation was observed even when the aqueous suspension was placed unattended for 3 months.

The XRD pattern of luteolin (Figure 3a) shows sharp crystalline peaks with the $2 \theta$ of $10.3,14.4,16.1,20.4,21.2$, $22.8,23.0,24.6,25.5,26.4,27.2,28.2$, and $29.2^{\circ}$, indicating crystallinity of this compound. In contrast, no $2 \theta$ scattering peak can be observed for Product 3 (Figure 3a), suggesting that Product 3 nanoparticles are amorphous. The crystallinity and amorphous states of luteolin and Product 3 also agree well with the higher decomposition temperature of luteolin (379 ${ }^{\circ} \mathrm{C}$ ) compared to that of Product $3\left(188^{\circ} \mathrm{C}\right)$.

The changes in weight percentage of the materials as a function of temperature were measured by thermogravimetric analysis (TGA) in the differential thermal analysis mode (TGDTA). The DTA curves of the two starting materials used in the preparation of Product 3, luteolin and PEG 2050 (Figure S4a,b in the SI), show single sharp peaks at 367.8 and 391.2 ${ }^{\circ} \mathrm{C}$, respectively. Interestingly, the DTA curves of Product 3 (Figure S4c in the SI) shows five broad peaks at 92.0, 175.8, $278.9,389.1$, and $454.5^{\circ} \mathrm{C}$. It is obvious that none of these peaks matches those of luteolin or PEG 2050. This implies that neither luteolin nor PEG 2050 was left as a physical mixture in Product 3. The DSC curves of luteolin and PEG 2050 (Figure S4e in the SI) show glass transition $\left(T_{\mathrm{g}}\right)$ at -110.0 and -109.7 ${ }^{\circ} \mathrm{C}$, and the two materials melt $\left(T_{\mathrm{m}}\right)$ at 171.3 and $56.6{ }^{\circ} \mathrm{C}$, respectively, whereas Product 3 shows $T_{\mathrm{g}}$ at only $-110.7^{\circ} \mathrm{C}$. The higher degradation temperature of luteolin $\left(367.8^{\circ} \mathrm{C}\right)$ compared to those of Product 3, and the sharp melting 


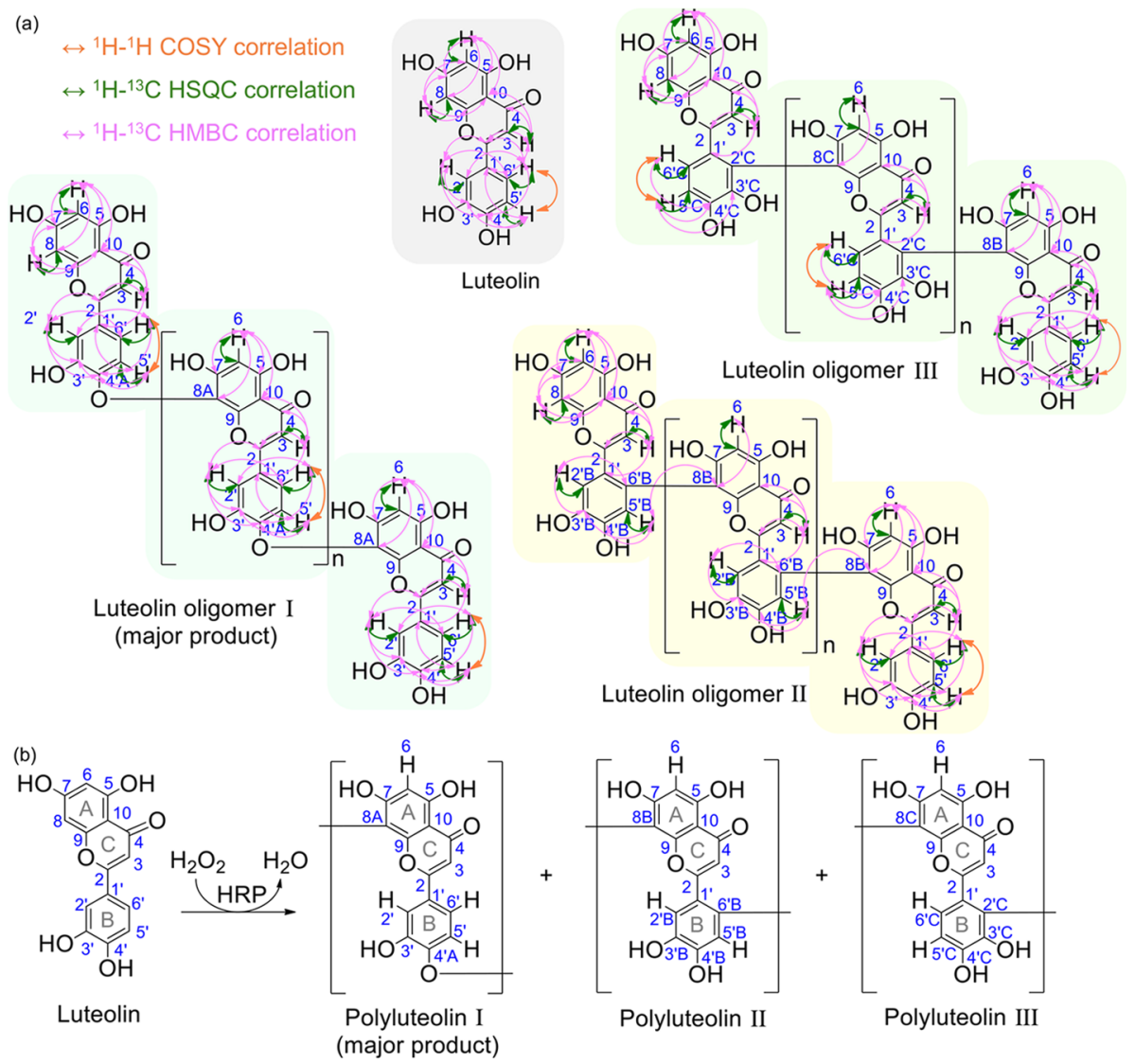

Figure 5. (a) Key ${ }^{1} \mathrm{H}-{ }^{1} \mathrm{H}$ COSY, ${ }^{1} \mathrm{H}-{ }^{13} \mathrm{C}$ HSQC, and ${ }^{1} \mathrm{H}-{ }^{13} \mathrm{C}$ HMBC correlations of luteolin and luteolin oligomer. (b) Proposed structures of polyluteolin.

temperature of luteolin agree with the above-mentioned XRD result, which indicates that luteolin is crystalline. These differences in thermal properties align well with the different crystallinity properties and different chemical structures of luteolin and Product 3.

The GFC profile (Figure $3 \mathrm{~b}$ ) indicates that Product 3 is a mixture of polyluteolin of various molecular masses. Approximately $88.3 \%$ of Product 3 are polyluteolin with molecular masses of $871147500-5400 \mathrm{Da}\left(M_{\mathrm{w}}\right.$ of $410000 \mathrm{Da}, M_{\mathrm{n}}$ of $130000 \mathrm{Da}$, retention time of $8.5-17.0 \mathrm{~min}$ ) and $11.7 \%$ are polyluteolin with molecular masses of 5400-18 Da $\left(M_{\mathrm{w}}\right.$ of 950 $\mathrm{Da}, M_{\mathrm{n}}$ of $195 \mathrm{Da}$, retention time of $\left.17.0-20.5 \mathrm{~min}\right)$. It is very likely that this latter potion of the small- $M_{\mathrm{w}}$ polyluteolin was actually the material in the ethanolic extract of Product 3 because the ethanolic extract of Product 3 coincidentally accounted for $11.2 \%$ of whole Product 3 .

Attempts to directly elucidate chemical structures of Product 3 cannot be accomplished due to the severe broadening of NMR resonance peaks. The broadening of peaks was probably caused by the slower molecular motion of polymer chains, which leads to repeating units being situated in slightly different chemical environments. Therefore, to elucidate the chemical structure and propose the reaction mechanism of polymerization, the luteolin oligomer was extracted from Product 3 and characterized by ${ }^{1} \mathrm{H},{ }^{13} \mathrm{C},{ }^{1} \mathrm{H}-{ }^{1} \mathrm{H}$ correlated spectroscopy (COSY), ${ }^{1} \mathrm{H}-{ }^{13} \mathrm{C}$ heteronuclear single-quantum coherence (HSQC), and ${ }^{1} \mathrm{H}-{ }^{13} \mathrm{C}$ HMBC NMR spectroscopy (Table 1, Figures 4 and 5, and Table S1 and Figures S5-S7 in the SI). Compared to the spectra of original luteolin, many changes are observed in the oligomers' spectra, e.g., a $75 \%$ decrease in the intensity of $\mathrm{H}_{8}$ resonance at $6.41 \mathrm{ppm}$ from 1:1 to $0.25: 1 \mathrm{H}_{8}: \mathrm{H}_{6}$ integral ratio and decreases in $\mathrm{HMBC}$ correlations between $\mathrm{H}_{8}$ and all carbons. The HMBC spectrum of the oligomers shows new correlations between $\mathrm{H}_{6}$ and a new carbon peak at $177.03 \mathrm{ppm}$. It is likely that this $\mathrm{C}_{8}$ in a new environment (designated as $\mathrm{C}_{8 \mathrm{~A}}$ ) is the connecting point between one unit of the luteolin monomer and the next unit. With the downfield resonance of $\mathrm{C}_{8 \mathrm{~A}}$, its connection to an electronegative atom is quite possible. For finding where this $\mathrm{C}_{8 \mathrm{~A}}$ is connected to, we have identified a small downfield shift from 149.65 of the original $\mathrm{C}_{4^{\prime}}$ to $154.38 \mathrm{ppm}$. Confirming with $\mathrm{HMBC}$ correlations to $\mathrm{H}_{5^{\prime}}$ and $\mathrm{H}_{2^{\prime}}$, this carbon is $\mathrm{C}_{4^{\prime}}$ in the new environment (designated as $\mathrm{C}_{4 \mathrm{~A}}$ ). It is likely that the hydroxyl group on original $\mathrm{C}_{4}$ changes to an ether functionality to produce $\mathrm{C}_{4 \mathrm{~A}}$. We propose that $\mathrm{C}_{8 \mathrm{~A}}$ (in flavonoid ring $\mathrm{A}$ ) of one luteolin oligomeric unit is connected to $\mathrm{C}_{4^{\prime} \mathrm{A}}$ (in flavonoid ring $\mathrm{B}$ ) of another luteolin monomeric unit via an ether linkage. This oligomer is designated as oligomer I (see more $\mathrm{HMBC}$, COSY, and HSQC of this proposed oligomer I in Figure 5).

In addition to oligomer $\mathrm{I}$, a new singlet ${ }^{1} \mathrm{H}$ resonance peak at $7.51 \mathrm{ppm}$ can be observed. This new proton peak shows HMBC correlations to carbons at $150.77 \mathrm{ppm}\left(\mathrm{C}_{4^{\prime} \mathrm{B}}\right)$ and $148.34 \mathrm{ppm}\left(\mathrm{C}_{3^{\prime} \mathrm{B}}\right)$. Therefore, it is likely that this new singlet proton resonance peak represents $\mathrm{H}_{5^{\prime}}$ in the new environment (designated as $\mathrm{H}_{5^{\prime} \mathrm{B}}$ ). A new carbon peak at $123.12 \mathrm{ppm}$, which shows correlation to $\mathrm{H}_{6}$, is likely $\mathrm{C}_{8}$ in the new environment (designated as $\mathrm{C}_{8 \mathrm{~B}}$ ). The HMBC correlation of $\mathrm{H}_{5^{\prime} \mathrm{B}}$ to $\mathrm{C}_{8 \mathrm{~B}}$ indicates the connection of $\mathrm{C}_{8 \mathrm{~B}}$ (in flavonoid ring $\mathrm{A}$ ) to $\mathrm{C}_{6^{\prime} \mathrm{B}}$ (in flavonoid ring $\mathrm{B}$ ). The oligomer with this connection is 
(a)

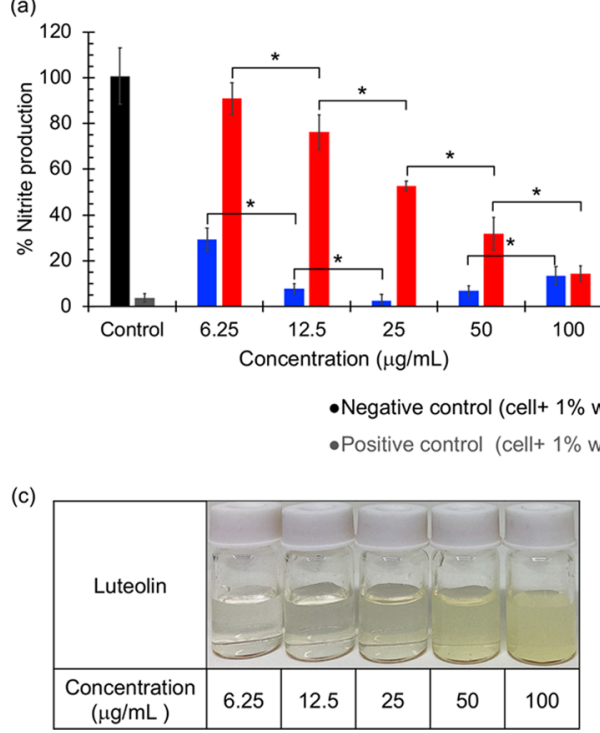

(b)

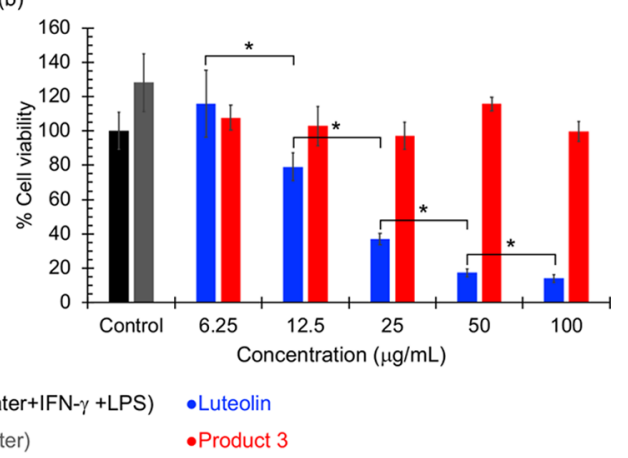

(d)

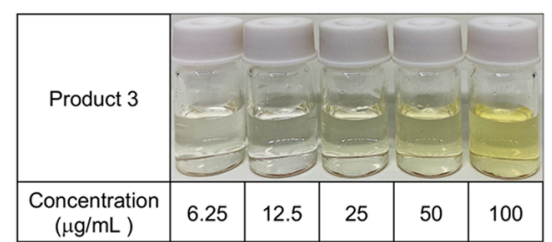

Figure 6. In vitro anti-inflammatory activity of luteolin and polyluteolin nanoparticles (Product 3): (a) \% nitrite production and (b) \% cell viability. Aqueous suspensions of (c) luteolin and (d) Product 3 at various concentrations. Significant differences between the tested groups were statistically analyzed using the $t$-test and were denoted with $*$ for a $p$ value of $<0.05$.

designated as oligomer II (see more HMBC, COSY, and HSQC of this proposed oligomer II in Figure 5).

In addition to oligomers I and II, oligomer III structure, where $\mathrm{C}_{8 \mathrm{C}}$ (from flavonoid ring $\mathrm{A}$ ) is connected to $\mathrm{C}_{2^{\prime} \mathrm{C}}$ (in flavonoid ring B), is also proposed based on COSY (see $\mathrm{H}_{5^{\prime} \mathrm{C}}-$ $\mathrm{H}_{6^{\prime} \mathrm{C}}$ correlation of oligomer III in Figure S5), HMBC, HSQC, and splitting pattern of the ${ }^{1} \mathrm{H}$ NMR spectra (Figure 5 and Table S1).

It should be noted here that the three types of connections proposed here for the oligomerized luteolin products resemble the connections previously proposed for polymerized tea polyphenols. $^{22-29}$ Among the three identified oligomers, oligomer I is the most abundant (the highest integral of the ${ }^{1} \mathrm{H}$ NMR resonance peaks). Apart from the three proposed structures, some other minor unidentified structures are also present in the extracted oligomerized products used in the analyses.

Due to the oxidative nature of the three oligomers and the requirement of both $\mathrm{H}_{2} \mathrm{O}_{2}$ and $\mathrm{PPO}$, it is likely that the oxidative polymerization proceeds via a free-radical mechanism. The ortho diphenolic moieties on the flavonoid ring $B$ are the first oxidative points, resulting in an intermediate with diketo moieties on ring $\mathrm{B}$. The electron-rich site at the 8 position in flavonoid ring $A$ of another unit then reacts with this oxidized intermediate at three different positions, resulting in three different connection types (Figure S7 in the SI).

Anti-inflammatory activity of luteolin and Product 3 was determined in RAW 264.7 macrophage cells by measuring nitrite accumulation in the culture supernatant via the Griess assay after triggering the cells with LPS. ${ }^{36}$ As shown in Figure 6a, RAW 264.7 macrophages (positive control) produced low levels of nitrite $(3.76 \pm 1.92 \%$, relative to negative control). Nitrite production increased after cells were activated with LPS for $24 \mathrm{~h}$ (100.72 $\pm 12.23 \%$, negative control). Luteolin strongly suppressed nitrite production in a dose-dependent manner. To investigate that the observed anti-inflammatory activity was not the result of cell death, cell viability at various concentrations of the tested materials was acquired by the 3(4,5-dimethylthiazol-2-yl)-2,5-diphenyl tetrazolium bromide
(MTT) assay. $^{37}$ Luteolin shows cytotoxicity in a dosedependent manner with more than 20,60, and $80 \%$ cell death at $12.5,25$, and $50 \mu \mathrm{g} / \mathrm{mL}$, respectively (Figure $6 \mathrm{~b}$ ). Therefore, the high anti-inflammatory activities of luteolin at concentrations of $12.5 \mu \mathrm{g} / \mathrm{mL}$ and higher indicated from the reduced cellular nitrite production assay are, in fact, a result of cell death but not the true anti-inflammatory activity.

Although not as strongly as luteolin, the $t$-test analysis confirms that Product 3 significantly inhibits the nitrite production in a dose-dependent manner, with almost complete suppression at $100 \mu \mathrm{g} / \mathrm{mL}$ (Figure 6a). Interestingly, unlike luteolin that is cytotoxic in a dose-dependent manner, Product 3 shows no cytotoxicity even at the highest concentration tested $(100 \mu \mathrm{g} / \mathrm{mL})$ (Figure $6 \mathrm{~b})$. The $t$-test analysis indicates no significant difference (at a $p$ value of 0.05 ) among cell viabilities of negative control and Product 3 of various concentrations (Figure $6 \mathrm{~b}$ ). These results confirm that the anti-inflammatory activity observed for Product 3 was not a result of cytotoxicity of the material but the real antiinflammatory action of the compound. As a result, we conclude that Product 3 is noncytotoxic even at high concentrations and possesses dose-dependent anti-inflammatory activity.

As mentioned earlier that there might be some PEG in Product 3; therefore, to make sure that the anti-inflammatory activity observed for Product 3 was not caused by PEG, we tested the anti-inflammatory activity of PEG at the highest possible concentrations of PEG in each sample (assuming that no PEG was eliminated during dialysis). The result (Figure S8 in the SI) confirms no anti-inflammatory activity of PEG.

\section{CONCLUSIONS}

This paper demonstrates the conversion of luteolin into a water-dispersible polymerized product. The polymerization reaction, induced by a catalytic amount of $\mathrm{HRP}$ and $\mathrm{H}_{2} \mathrm{O}_{2}$, is coupled to the product self-assembly induced by a small amount of PEG to produce polyluteolin nanoparticles at 89.3 $\pm 4.8 \%$ yield. When prepared at an optimized condition, the spherical polyluteolin nanoparticles are amorphous with a dry 
Table 2. Amount of Materials Used in the Synthesis of Polyluteolin Nanoparticles

\begin{tabular}{|c|c|c|c|c|c|c|c|c|c|}
\hline \multirow[b]{2}{*}{ Product } & \multirow{2}{*}{$\frac{\text { Luteolin }}{\mathrm{mg}}$} & \multicolumn{2}{|c|}{ PEG } & \multicolumn{2}{|r|}{ HRP } & \multirow{2}{*}{$\frac{30 \% \mathrm{H}_{2} \mathrm{O}_{2}}{\mathrm{~mL}}$} & \multirow{2}{*}{$\frac{\mathrm{PB} \mathrm{pH} 7.4}{\mathrm{~mL}}$} & \multirow{2}{*}{$\frac{\text { Ethanol }}{\mathrm{mL}}$} & \multirow[b]{2}{*}{$\%$ yield } \\
\hline & & $M_{\mathrm{w}}$ & $\mathrm{mg}$ & $\mathrm{mg}$ & $\%$ relatively to luteolin & & & & \\
\hline 1 & 75.0 & 2050 & 7.5 & 0.0 & 0.0 & 3.6 & 26.4 & 15.0 & $\mathrm{NR}^{a}$ \\
\hline 2 & 75.0 & 2050 & 7.5 & 1.25 & 1.7 & 3.6 & 26.4 & 15.0 & $\mathrm{NR}^{a}$ \\
\hline 3 & 75.0 & 2050 & 7.5 & 2.5 & 3.3 & 3.6 & 26.4 & 15.0 & $89.3 \pm 4.8$ \\
\hline 4 & 75.0 & 2050 & 7.5 & 2.5 & 3.3 & 0.0 & 26.4 & 15.0 & $\mathrm{NR}^{a}$ \\
\hline 5 & 75.0 & & 0.0 & 2.5 & 3.3 & 3.6 & 26.4 & 15.0 & $67.9 \pm 0.9$ \\
\hline 6 & 75.0 & 200 & 7.5 & 2.5 & 3.3 & 3.6 & 26.4 & 15.0 & $56.7 \pm 2.2$ \\
\hline 7 & 75.0 & 35000 & 7.5 & 2.5 & 3.3 & 3.6 & 26.4 & 15.0 & $69.7 \pm 2.6$ \\
\hline
\end{tabular}

${ }^{a} \mathrm{NR}$, no polymerization reaction.

size of $234.8 \pm 101.6 \mathrm{~nm}$ and an aqueous size distribution of $379.1 \pm 220.5 \mathrm{~nm}(\mathrm{PDI}=0.338)$ and contains polyluteolin with $M_{\mathrm{w}}$ of $410000 \mathrm{Da}$ and $M_{\mathrm{n}}$ of $130000 \mathrm{Da}$. Analyses of ${ }^{1} \mathrm{H}-{ }^{1} \mathrm{H}$ COSY, ${ }^{1} \mathrm{H}-{ }^{13} \mathrm{C}$ HSQC, and ${ }^{1} \mathrm{H}-{ }^{13} \mathrm{C}$ HMBC NMR spectra and splitting patterns of ${ }^{1} \mathrm{H}$ reveal three different connections of luteolin monomeric units in polyluteolin: (1) the bonding of carbon 8 in flavonoid ring $\mathrm{A}$ of one monomeric unit via an ether bond to $\mathrm{C}_{4^{\prime} \mathrm{A}}$ in flavonoid ring $\mathrm{B}$ of the next unit, (2) $\mathrm{C}-\mathrm{C}$ bonding between $\mathrm{C}_{8 \mathrm{~B}}$ in ring $\mathrm{A}$ of one monomeric unit and $\mathrm{C}_{6^{\prime} \mathrm{B}}$ of ring $\mathrm{B}$ of the next unit, and (3) the $\mathrm{C}-\mathrm{C}$ connection of $\mathrm{C}_{8 \mathrm{C}}$ of ring $\mathrm{A}$ of one monomeric unit to $\mathrm{C}_{2^{\prime} \mathrm{C}}$ of ring $\mathrm{B}$ of the next unit. Unlike luteolin that is cytotoxic at high doses, polyluteolin nanoparticles (Product 3 ) possess dose-dependent anti-inflammatory activity with no cytotoxicity at high doses. We anticipate that these water-dispersible antiinflammatory polyluteolin nanoparticles could be further developed into an anti-inflammatory agent for therapeutic purposes.

\section{EXPERIMENTAL SECTION}

4.1. Synthesis of Polyluteolin Nanoparticles. To synthesize the polyluteolin nanoparticles, $75 \mathrm{mg}$ of luteolin (98\% w/w, Shaanxi Kingsci Biotechnology, China) was dissolved in $15 \mathrm{~mL}$ of ethanol and then $7.5 \mathrm{mg}$ of poly(ethylene glycol) (PEG, Sigma-Aldrich, Germany) in 2 $\mathrm{mL}$ of $0.01 \mathrm{M}$ phosphate buffer $\mathrm{pH} 7.4(\mathrm{~PB} \mathrm{pH} 7.4)$ was added while stirring (200 rpm, C-MAG HS 7, IKA, Germany) at room temperature. After that, horseradish peroxidase (HRP, Health Biochem Technology, China) in $2 \mathrm{~mL}$ of $\mathrm{PB} \mathrm{pH} 7.4$ and $3.6 \mathrm{~mL}$ of $30 \% \mathrm{H}_{2} \mathrm{O}_{2}$ were added, respectively. The effects of HRP concentration, presence of $\mathrm{H}_{2} \mathrm{O}_{2}$, and molecular mass of PEG were investigated (see the amount in Table 2). Next, phosphate buffer $\mathrm{pH} 7.4$ was added dropwise to the mixture (to $45 \mathrm{~mL}$ of total volume) and then the mixture was stirred at room temperature for $24 \mathrm{~h} . \mathrm{H}_{2} \mathrm{O}_{2}$ and ethanol were eliminated by dialysis (dialysis tubing cellulose membrane molecular cutoff 14000, Sigma-Aldrich).

The resulting aqueous suspension of the product was collected and subjected to scanning electron microscopy analyses (SEM, JSM-IT100 JEOL, Japan). Dry products were obtained by freeze-drying the suspension (FreeZone 6 Liter50C Console Freeze Dryer, Labconco Corporation) and subjected to ${ }^{1} \mathrm{H}$ NMR spectrophotometric $(20 \mathrm{mg} / \mathrm{mL}$ in dimethyl sulfoxide-d6 (DMSO- $d_{6}$ ), JNM-ECZR $500 \mathrm{MHz}$, JEOL, Japan), UV-vis spectrophotometric $(10 \mu \mathrm{g} / \mathrm{mL}$ in DMSO, Optizen POP QX, K LAB, Korea), and attenuated total reflectance Fourier transform infrared (ATR FT-IR) spectrophotometric analyses (Nicolet 6700, Thermo Electron Corporation). The particle size distribution and $\zeta$-potential of the polyluteolin nanoparticles in aqueous suspension were determined by the dynamic light scattering (DLS) technique using a Zetasizer instrument $(\mathrm{RI}=1.441$, Zetasizer Nano ZS, Malvern Instruments, Worcestershire, U.K.). The polyluteolin nanoparticle was analyzed by powder X-ray diffraction (XRD, scanning rate $10-60^{\circ}$ in the $2 \theta$ range, scan speed $5^{\circ} / \mathrm{min}$ in $0.02^{\circ}$ step size, voltage $40 \mathrm{kV}$, electronic current $30 \mathrm{~mA}, \mathrm{X}$-ray diffractometer DMAX 2200/Ultima, Rigaku, Japan), thermogravimetric analysis (TGA, scanned from 50 to $850{ }^{\circ} \mathrm{C}$ at a heating rate of $20{ }^{\circ} \mathrm{C} / \mathrm{min}$ under nitrogen gas, PerkinElmer Pyris 1 TGA), and differential scanning calorimetry (DSC, scanned from -130 to $250{ }^{\circ} \mathrm{C}$ (for luteolin and PEG) and $-130-250{ }^{\circ} \mathrm{C}$ (for Product 3 ) at a heating rate of $10{ }^{\circ} \mathrm{C} / \mathrm{min}$ under nitrogen gas, NETZSCH DSC 204F1 Phoenix, Germany). Weight-average molecular mass $\left(M_{\mathrm{w}}\right)$ of polyluteolin or luteolin oligomers was investigated by gel filtration chromatography (GFC with a photodiode array detector set at $254 \mathrm{~nm}, 10 \mathrm{mg} / \mathrm{mL}$ sample concentration, $50 \mu \mathrm{L}$ injection volume, $1 \mathrm{~mL} / \mathrm{min}$ flow rate, Shimadzu Prominence HPLC series equipped with Shodex SB-803 HQ and SB-806 HQ columns) using $N, N$-dimethylformamide (DMF) as a solvent and polystyrenes $\left(M_{\mathrm{p}}=580,9820,67600,466300\right.$, and $3152000 \mathrm{Da})$ as standards. The percent yield is defined as follows

$$
\text { yield }(\%)=\frac{\text { weight of product }}{\text { weight of luteolin }+ \text { weight of PEG }+ \text { weight of HRP }} \times 100
$$

The percent yield is reported as the average and standard deviation of three independent samples.

4.2. Preparation of Luteolin Oligomers. Product 3 (Table 2) was prepared as described above. Small oligomeric products or luteolin oligomers (soluble in ethanol) were extracted by dissolving Product 3 in ethanol, the obtained ethanolic suspension was filtered through a $0.22 \mu \mathrm{m}$ syringe filter, and the filtered solution was dried under vacuum. The obtained product was subjected to ${ }^{1} \mathrm{H},{ }^{13} \mathrm{C}, \mathrm{COSY}$, HSQC, and HMBC NMR analyses in methanol-d4 (500 MHz NMR spectrometer, JNM-ECZR $500 \mathrm{MHz}$, JEOL, Japan), and UVvisible absorption analysis in acetone (Optizen POP QX, K LAB, Korea).

Luteolin: light yellow powder; decomposition temperature of $379{ }^{\circ} \mathrm{C}$; ${ }^{1} \mathrm{H}$ NMR (DMSO- $\left.d_{6}, 500 \mathrm{MHz}\right): \delta 7.36(2 \mathrm{H}, \mathrm{m}$, $\mathrm{H}_{2^{\prime}}$ and $\left.\mathrm{H}_{6^{\prime}}\right), 6.84\left(1 \mathrm{H}, \mathrm{d}, J=8.5 \mathrm{~Hz}, \mathrm{H}_{5^{\prime}}\right), 6.63\left(1 \mathrm{H}, \mathrm{s}, \mathrm{H}_{3}\right)$, $6.40\left(1 \mathrm{H}, \mathrm{d}, J=2.0 \mathrm{~Hz}, \mathrm{H}_{8}\right)$, and $6.15\left(1 \mathrm{H}, \mathrm{d}, J=2.0 \mathrm{~Hz}, \mathrm{H}_{6}\right)$; ${ }^{13} \mathrm{C}$ NMR (DMSO- $\left.d_{6}, 500 \mathrm{MHz}\right): \delta 181.66\left(\mathrm{~s}, \mathrm{C}_{4}\right), 164.33(\mathrm{~s}$, $\mathrm{C}_{7}$ ), $163.88\left(\mathrm{~s}, \mathrm{C}_{2}\right), 161.49\left(\mathrm{~s}, \mathrm{C}_{5}\right), 157.32\left(\mathrm{~s}, \mathrm{C}_{9}\right), 149.79$ (s, $\left.\mathrm{C}_{4}{ }^{\prime}\right), 145.77\left(\mathrm{~s}, \mathrm{C}_{3^{\prime}}\right), 121.45\left(\mathrm{~s}, \mathrm{C}_{1^{\prime}}\right), 119.02\left(\mathrm{~s}, \mathrm{C}_{6^{\prime}}\right), 116.02(\mathrm{~s}$, $\left.\mathrm{C}_{5^{\prime}}\right), 113.33\left(\mathrm{~s}, \mathrm{C}_{2^{\prime}}\right), 103.64\left(\mathrm{~s}, \mathrm{C}_{10}\right), 102.84\left(\mathrm{~s}, \mathrm{C}_{3}\right), 98.88(\mathrm{~s}$, $\left.\mathrm{C}_{6}\right)$, and $93.88\left(\mathrm{~s}, \mathrm{C}_{8}\right)$; ATR FT-IR $\left(\mathrm{cm}^{-1}\right): 3417$ (brd, O-H stretching), 1653 (str, $\mathrm{C}=\mathrm{O}$ stretching of the aromatic 
ketone), 1606, 1574, 1500 (str, $\mathrm{C}=\mathrm{C}$ stretching of aromatic ring), 1365, 1263, 1246 (str, C-O stretching of phenol), 1164, 1030 (str, C-O stretching of ether in the aromatic ring); UVvisible absorption $\left(\lambda_{\max }\right.$ in DMSO): $271 \mathrm{~nm}\left(\pi-\pi^{*}\right.$ of the benzoyl system) and $353 \mathrm{~nm}\left(\mathrm{n}-\pi^{*}\right.$ of the cinnamoyl system), and UV-visible absorption ( $\lambda_{\max }$ in acetone): $340 \mathrm{~nm}\left(\mathrm{n}-\pi^{*}\right.$ of the cinnamoyl system).

Product 1: light yellow powder; decomposition temperature of $312{ }^{\circ} \mathrm{C}$; ${ }^{1} \mathrm{H}$ NMR (DMSO- $\left.d_{6}, 500 \mathrm{MHz}\right): \delta 7.36(2 \mathrm{H}, \mathrm{m}$, $\mathrm{H}_{2^{\prime}}$ and $\left.\mathrm{H}_{6^{\prime}}\right), 6.84\left(1 \mathrm{H}, \mathrm{d}, J=8.5 \mathrm{~Hz}, \mathrm{H}_{5^{\prime}}\right), 6.63\left(1 \mathrm{H}, \mathrm{s}, \mathrm{H}_{3}\right)$, $6.40\left(1 \mathrm{H}, \mathrm{d}, J=2.0 \mathrm{~Hz}, \mathrm{H}_{8}\right)$, and $6.15\left(1 \mathrm{H}, \mathrm{d}, J=2.0 \mathrm{~Hz}, \mathrm{H}_{6}\right)$; ATR FT-IR $\left(\mathrm{cm}^{-1}\right)$ : 3408 (brd, O-H stretching), 1651 (str, $\mathrm{C}=\mathrm{O}$ stretching of the aromatic ketone), 1602, 1574, 1498 (str, $\mathrm{C}=\mathrm{C}$ stretching of the aromatic ring), 1365, 1261, 1246 (str, C-O stretching of phenol), 1165, 1030 (str, C-O stretching of ether in aromatic ring); UV-visible absorption ( $\lambda_{\max }$ in DMSO): $271\left(\pi-\pi^{*}\right)$ and $353 \mathrm{~nm}\left(\mathrm{n}-\pi^{*}\right)$.

Product 2: dark yellow powder; decomposition temperature of $212{ }^{\circ} \mathrm{C} ;{ }^{1} \mathrm{H}$ NMR (DMSO- $\left.d_{6}, 500 \mathrm{MHz}\right): \delta 7.36(2 \mathrm{H}, \mathrm{m}$, $\mathrm{H}_{2^{\prime}}$ and $\left.\mathrm{H}_{6^{\prime}}\right), 6.84\left(1 \mathrm{H}, \mathrm{d}, J=8.5 \mathrm{~Hz}, \mathrm{H}_{5^{\prime}}\right), 6.63\left(1 \mathrm{H}, \mathrm{s}, \mathrm{H}_{3}\right)$, $6.40\left(1 \mathrm{H}, \mathrm{d}, J=2.0 \mathrm{~Hz}, \mathrm{H}_{8}\right)$, and $6.15\left(1 \mathrm{H}, \mathrm{d}, J=2.0 \mathrm{~Hz}, \mathrm{H}_{6}\right)$; ATR FT-IR ( $\left.\mathrm{cm}^{-1}\right)$ : 3207 (brd, O-H stretching), 2908 (brd, $\mathrm{sp}^{3} \mathrm{C}-\mathrm{H}$ stretching), 1623 (str, $\mathrm{C}=\mathrm{O}$ stretching of aromatic ketone), 1604,1504 (str, $\mathrm{C}=\mathrm{C}$ stretching of aromatic ring), 1352, 1255 (str, C-O stretching of phenol), 1162, 1028 (str, $\mathrm{C}-\mathrm{O}$ stretching of ether in aromatic ring); UV-visible absorption ( $\lambda_{\max }$ in DMSO): $269\left(\pi-\pi^{*}\right)$ and $353 \mathrm{~nm}\left(\mathrm{n}-\pi^{*}\right)$.

Product 3: light brown powder; decomposition temperature of $188{ }^{\circ} \mathrm{C}$; ATR FT-IR $\left(\mathrm{cm}^{-1}\right): 3265$ (brd, O-H stretching), 2914 (brd, $\mathrm{sp}^{3} \mathrm{C}-\mathrm{H}$ stretching), 1630 (str, $\mathrm{C}=\mathrm{O}$ stretching of aromatic ketone), 1612, 1504 (str, $\mathrm{C}=\mathrm{C}$ stretching of aromatic ring), 1354, 1257 (str, C-O stretching of phenol), 1163, 1028 (str, C-O stretching of ether in aromatic ring); UV-visible absorption ( $\lambda_{\max }$ in DMSO): $262\left(\pi-\pi^{*}\right)$ and 318 $\mathrm{nm}\left(\mathrm{n}-\pi^{*}\right)$.

Product 4: light brown powder; decomposition temperature $315{ }^{\circ} \mathrm{C}$; ${ }^{1} \mathrm{H}$ NMR (DMSO- $\left.d_{6}, 500 \mathrm{MHz}\right): \delta 7.36(2 \mathrm{H}, \mathrm{m}$, $\mathrm{H}_{2^{\prime}}$ and $\left.\mathrm{H}_{6^{\prime}}\right), 6.84\left(1 \mathrm{H}, \mathrm{d}, J=8.5 \mathrm{~Hz}, \mathrm{H}_{5^{\prime}}\right), 6.63\left(1 \mathrm{H}, \mathrm{s}, \mathrm{H}_{3}\right)$, $6.40\left(1 \mathrm{H}, \mathrm{d}, J=2.0 \mathrm{~Hz}, \mathrm{H}_{8}\right)$, and $6.15\left(\mathrm{~d}, 1 \mathrm{H}, J=2.0 \mathrm{~Hz}, \mathrm{H}_{6}\right)$; ATR FT-IR $\left(\mathrm{cm}^{-1}\right)$ : 3145 (brd, O-H stretching), 1647 (str, $\mathrm{C}=\mathrm{O}$ stretching of aromatic ketone), 1597, 1576, 1506 (str, $\mathrm{C}=\mathrm{C}$ stretching of aromatic ring), 1363, 1246 (str, C-O stretching of phenol), 1159, 1026 (str, C-O stretching of ether in aromatic ring); UV-visible absorption ( $\lambda_{\max }$ in DMSO): $271\left(\pi-\pi^{*}\right)$ and $353 \mathrm{~nm}\left(\mathrm{n}-\pi^{*}\right)$.

Product 5: light brown powder; decomposition temperature of $264{ }^{\circ} \mathrm{C}$; ATR FT-IR $\left(\mathrm{cm}^{-1}\right)$ : 3400, 3197 (brd, O-H stretching), 1651 (str, $\mathrm{C}=\mathrm{O}$ stretching of aromatic ketone), $1610,1558,1500$ (str, $\mathrm{C}=\mathrm{C}$ stretching of the aromatic ring), 1354, 1257 (str, C-O stretching of phenol), 1165, 1030 (str, $\mathrm{C}-\mathrm{O}$ stretching of ether in the aromatic ring); UV-visible absorption ( $\lambda_{\max }$ in DMSO): $265\left(\pi-\pi^{*}\right)$ and $340 \mathrm{~nm}\left(\mathrm{n}-\pi^{*}\right)$.

Product 6: light brown powder; decomposition temperature of $187^{\circ} \mathrm{C}$; ATR FT-IR $\left(\mathrm{cm}^{-1}\right): 3209$ (brd, O-H stretching), 2953 (brd, $\mathrm{sp}^{3} \mathrm{C}-\mathrm{H}$ stretching), 1651 (str, $\mathrm{C}=\mathrm{O}$ stretching of the aromatic ketone), 1608,1506 (str, $\mathrm{C}=\mathrm{C}$ stretching of the aromatic ring), 1354, 1257 (str, C-O stretching of phenol), 1163,1022 (str, C-O stretching of ether in the aromatic ring); UV-visible absorption ( $\lambda_{\max }$ in DMSO): $262\left(\pi-\pi^{*}\right)$ and 293 $\mathrm{nm}\left(\mathrm{n}-\pi^{*}\right)$.

Product 7: light brown powder; decomposition temperature of $212{ }^{\circ} \mathrm{C}$; ATR FT-IR $\left(\mathrm{cm}^{-1}\right): 3348$ (brd, O-H stretching), 2920 (brd, sp ${ }^{3} \mathrm{C}-\mathrm{H}$ stretching), 1637 (str, $\mathrm{C}=\mathrm{O}$ stretching of the aromatic ketone), 1614,1504 (str, $\mathrm{C}=\mathrm{C}$ stretching of the aromatic ring), 1352, 1259 (str, C-O stretching of phenol), 1165,1024 (str, C-O stretching of ether in the aromatic ring); UV-visible absorption ( $\lambda_{\max }$ in DMSO): $274\left(\pi-\pi^{*}\right)$ and 340 $\mathrm{nm}\left(\mathrm{n}-\pi^{*}\right)$.

Luteolin oligomer: dark yellow powder; Yield 11.2\% weight of Product 3; dark yellow powder; UV-visible absorption $\left(\lambda_{\max }\right.$ in acetone $): 332 \mathrm{~nm}\left(\mathrm{n}-\pi^{*}\right)$. See its NMR spectra in the Results and Discussion section.

4.3. In Vitro Anti-inflammatory Activity. The in vitro anti-inflammatory activity of polyluteolin nanoparticles and luteolin was determined through the nitrite production level of RAW 264.7 macrophage cells (ATCC, Manassas) using the Griess assay. The samples include the polyluteolin nanoparticle (Product 3) and luteolin at the concentrations of 6.25, 12.5, 25,50 , and $100 \mu \mathrm{g} / \mathrm{mL}$ and PEG 2050 at the concentrations of $0.625,1.25,2.5,5$, and $10 \mu \mathrm{g} / \mathrm{mL}$. Effects of samples on RAW 264.7 cell viability were also acquired using the MTT assay to confirm that the obtained anti-inflammatory activity was not related to the cytotoxicity of the samples.

4.3.1. Cell Culture and Treatment. RAW 264.7 cells were cultured in complete media of Dulbecco's modified Eagle's medium (DMEM, Hyclone), 10\% fetal bovine serum (FBS, Hyclone), 1\% 4-[2-hydroxyethyl]-1-piperazineethanesulfonic acid (HEPES, Hyclone), $1 \%$ sodium pyruvate (Hyclone), and $1 \%$ gentamicin (Hyclone) at $37{ }^{\circ} \mathrm{C}$ in an atmosphere of $5 \%$ $\mathrm{CO}_{2}$ for $72 \mathrm{~h}$. After that, the cells were seeded in a 96-well plate $(10000$ cell/well $)$ overnight. Then, the supernatant was removed and replaced by the sample ( $50 \mu \mathrm{L} /$ well), and the plate was incubated at $37{ }^{\circ} \mathrm{C}$ in an atmosphere of $5 \% \mathrm{CO}_{2}$ for $1 \mathrm{~h}$. After that, complete media containing LPS $(200 \mathrm{ng} / \mathrm{mL}$, Sigma-Aldrich) and recombinant IFN- $\gamma(20 \mathrm{ng} / \mathrm{mL}$, BioLegend) was added ( $50 \mu \mathrm{L} /$ well). The cells were incubated at $37{ }^{\circ} \mathrm{C}$ in an atmosphere of $5 \% \mathrm{CO}_{2}$ for $24 \mathrm{~h}$. Culture supernatants were collected from the treated cells and subjected for the nitric oxide assay (Section 4.3.2) while cells were subjected for viability by the MTT assay (Section 4.3.3).

4.3.2. Nitrite Production. Nitrite production was measured by nitrite accumulation in the culture supernatant using a colorimetric reaction. For analysis, the supernatant $(50 \mu \mathrm{L})$ of the treated cells from Section 4.3.1 was mixed with Griess reagent ( $50 \mu \mathrm{L} /$ well $0.1 \% N$-1-napthylethylenediamine dihydrochloride (NED, Sigma-Aldrich) and $50 \mu \mathrm{L} /$ well $1 \%$ sulfanilamide (Merck, Germany) in 5\% phosphoric acid). The absorbance was measured at $540 \mathrm{~nm}$ (microplate reader, Multiskan FC, Thermo Scientific), and the nitrite concentration was determined with the aid of the standard curve constructed from standard sodium nitrite solutions prepared in complete media. Cells treated with $1 \%$ water, IFN- $\gamma$, and LPS in complete media were used as a negative control, and cells treated with $1 \%$ water in complete media were used as a positive control. Nitrite production is defined as follows

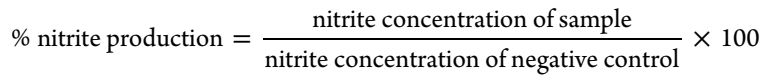

The nitrite production is reported as the average and standard deviation of results from three independent experiments.

4.3.3. Cell Viability. Cell metabolism was measured by the reduction of 3-(4,5-dimethylthiazol-2-yl)-2,5-diphenyl tetrazolium bromide (MTT) to purple formazan using a colorimetric assay. All supernatants of the treated cells from Section 4.3.1 were removed and replaced with complete media $(100 \mu \mathrm{L} /$ well) and MTT solution ( $5 \mathrm{mg} / \mathrm{mL}$ in phosphate-buffered 
saline $\mathrm{pH} 7.4,10 \mu \mathrm{L} /$ well). After the treated cells were incubated at $37{ }^{\circ} \mathrm{C}$ in an atmosphere of $5 \% \mathrm{CO}_{2}$ for $4 \mathrm{~h}$, DMSO was added $(200 \mu \mathrm{L} /$ well $)$ to dissolve the formazan crystals. Then, the absorbance was measured at $540 \mathrm{~nm}$. Cells treated with $1 \%$ water, IFN $-\gamma$, and LPS in complete media were used as a negative control, cells treated with $1 \%$ water in complete media were used as a positive control, and complete media was used as a blank. Cell viability is defined as follows

$$
\% \text { cell viability }=\frac{\text { abs of sample }- \text { abs of blank }}{\text { abs of negative control }- \text { abs of blank }} \times 100
$$

The cell viability is reported as the average and standard deviation of results from three independent experiments.

4.3.4. Statistical Analysis. The data were reported as the average and standard deviation of three independent experiments. Statistical differences were analyzed by $t$-test analysis with the significance level at $\alpha=0.05$ for all tests. Significant differences between the tested groups are denoted with $*$ for $p$ value $<0.05$.

\section{ASSOCIATED CONTENT}

\section{(s) Supporting Information}

The Supporting Information is available free of charge at https://pubs.acs.org/doi/10.1021/acsomega.0c05142.

FT-IR spectra and UV spectra of products, particle size distribution graph, TG-DTA curves and DSC curves of polyluteolin nanoparticles (Product 3), overlay of ${ }^{1} \mathrm{H}-{ }^{1} \mathrm{H}$ COSY and ${ }^{1} \mathrm{H}-{ }^{13} \mathrm{C}$ HSQC NMR correlations, and proposed structure and reaction mechanism of the luteolin oligomer (PDF)

\section{AUTHOR INFORMATION}

\section{Corresponding Author}

Supason Wanichwecharungruang - Department of Chemistry, Faculty of Science, Chulalongkorn University, Bangkok 10330, Thailand; Center of Excellence on Petrochemical and Materials Technology and Center of Excellence in Advanced Materials and Biointerfaces, Chulalongkorn University, Bangkok 10330, Thailand; ○ orcid.org/0000-0002-2802-4341; Email: supason.p@ chula.ac.th

\section{Authors}

Parichat Tawornchat - Department of Chemistry, Faculty of Science, Chulalongkorn University, Bangkok 10330, Thailand; Center of Excellence on Petrochemical and Materials Technology, Chulalongkorn University, Bangkok 10330, Thailand

Thitiporn Pattarakankul - Center of Excellence in Advanced Materials and Biointerfaces, Chulalongkorn University, Bangkok 10330, Thailand

Tanapat Palaga - Department of Microbiology, Faculty of Science, Chulalongkorn University, Bangkok 10330, Thailand

Varol Intasanta - National Nanotechnology Center, National Science and Technology Development Agency, Pathumthani 12120, Thailand

Complete contact information is available at:

https://pubs.acs.org/10.1021/acsomega.0c05142

\section{Notes}

The authors declare no competing financial interest.

\section{ACKNOWLEDGMENTS}

This work was funded by the Center of Excellence on Petrochemical and Materials Technology (PETROMAT), Chulalongkorn University, the Center of Excellence in Advanced Materials and Biointerfaces, Chulalongkorn University, and the National Nanotechnology Center (NANOTEC), NSTDA, Ministry of Science and Technology, Thailand, through its program of Research Network NANOTEC (RNN).

\section{ABBREVIATIONS}

PEG, poly(ethylene glycol); $\mathrm{PB} \mathrm{pH} 7.4$, phosphate buffer $\mathrm{pH}$ 7.4; HRP, horseradish peroxidase; DMF, N,N-dimethylformamide; DMSO, dimethyl sulfoxide; GFC, gel filtration chromatography; LPS, lipopolysaccharides; IFN- $\gamma$, interferon $\gamma$

\section{REFERENCES}

(1) Perwez Hussain, S.; Harris, C. C. Inflammation and Cancer: an Ancient Link with Novel Potentials. Int. J. Cancer 2007, 121, 23732380.

(2) Lu, H.; Ouyang, W.; Huang, C. Inflammation, a Key Event in Cancer Development. Mol. Cancer Res. 2006, 4, 221-233.

(3) Greten, F. R.; Grivennikov, S. I. Inflammation and Cancer: Triggers, Mechanisms, and Consequences. Immunity 2019, 51, 2741.

(4) Zhang, H.; Tsao, R. Dietary Polyphenols, Oxidative Stress and Antioxidant and Anti-Inflammatory Effects. Curr. Opin. Food Sci. 2016, 8, 33-42.

(5) Wu, X.; Schauss, A. G. Mitigation of Inflammation with Foods. J. Agric. Food Chem. 2012, 60, 6703-6717.

(6) Benavente-García, O.; Castillo, J. Update on Uses and Properties of Citrus Flavonoids: New Findings in Anticancer, Cardiovascular, and Anti-Inflammatory Activity. J. Agric. Food Chem. 2008, 56, 61856205.

(7) Miean, K. H.; Mohamed, S. Flavonoid (Myricetin, Quercetin, Kaempferol, Luteolin, and Apigenin) Content of Edible Tropical Plants. J. Agric. Food Chem. 2001, 49, 3106-3112.

(8) Al-Megrin, W. A.; Alkhuriji, A. F.; Yousef, A. O. S.; Metwally, D. M.; Habotta, O. A.; Kassab, R. B.; Abdel Moneim, A. E.; El-Khadragy, M. F. Antagonistic Efficacy of Luteolin Against Lead Acetate Exposure-Associated with Hepatotoxicity is Mediated via Antioxidant, Anti-Inflammatory, and Anti-Apoptotic Activities. Antioxidants 2020, 9, 1-18.

(9) Aziz, N.; Kim, M. Y.; Cho, J. Y. Anti-Inflammatory Effects of Luteolin: A Review of In Vitro, In Vivo, and in Silico Studies. J. Ethnopharmacol. 2018, 225, 342-358.

(10) Hu, C.; Kitts, D. D. Luteolin and Luteolin-7-O-glucoside from Dandelion Flower Suppress iNOS and COX-2 in RAW264. 7 Cells. Mol. Cell. Biochem. 2004, 265, 107-113.

(11) Ueda, H.; Yamazaki, C.; Yamazaki, M. Luteolin as an AntiInflammatory and Anti-Allergic Constituent of Perilla frutescens. Biol. Pharm. Bull. 2002, 25, 1197-1202.

(12) Li, L.; Wu, X.; Chen, Z.; Sun, S.; Ye, J.; Zeng, S.; Jiang, H. Interspecies Difference of Luteolin and Apigenin after Oral Administration of Chrysanthemum Morifolium Extract and Prediction of Human Pharmacokinetics. Die Pharm. 2013, 68, 195-200.

(13) Liu, Y.; Wang, L.; Zhao, Y.; He, M.; Zhang, X.; Niu, M.; Feng, N. Nanostructured Lipid Carriers versus Microemulsions for Delivery of the Poorly Water-Soluble Drug Luteolin. Int. J. Pharm. 2014, 476, $169-177$.

(14) Qing, W.; Wang, Y.; Li, H.; Ma, F.; Zhu, J.; Liu, X. Preparation and Characterization of Copolymer Micelles for the Solubilization and In Vitro Release of Luteolin and Luteoloside. APPS PharmSciTech 2017, 18, 2095-2101.

(15) Majumdar, D.; Jung, K. H.; Zhang, H.; Nannapaneni, S.; Wang, X.; Amin, A. R.; Chen, Z.; Shin, D. M. Luteolin Nanoparticle in 
Chemoprevention: In Vitro and In Vivo Anticancer Activity. Cancer Prev. Res. 2014, 7, 65-73.

(16) Qiu, J. F.; Gao, X.; Wang, B. L.; Wei, X. W.; Gou, M. L.; Men, K.; Liu, X. Y.; Guo, G.; Qian, Z. Y.; Huang, M. J. Preparation and Characterization of Monomethoxy poly (ethylene glycol)-poly ( $\varepsilon$ caprolactone) Micelles for the Solubilization and In Vivo Delivery of Luteolin. Int. J. Nanomed. 2013, 8, 3061-3069.

(17) Tanaka, T.; Matsuo, Y.; Kouno, I. Chemistry of Secondary Polyphenols Produced During Processing of Tea and Selected Foods. Int. J. Mol. Sci. 2010, 11, 14-40.

(18) Natsume, M.; Osakabe, N.; Yamagishi, M.; Takizawa, T.; Nakamura, T.; Miyatake, H.; Hatano, T.; Yoshida, T. Analyses of Polyphenols in Cacao Liquor, Cocoa, and Chocolate by NormalPhase and Reversed-Phase HPLC. Biosci., Biotechnol., Biochem. 2000, 64, 2581-2587.

(19) Gao, Y.; Rankin, G. O.; Tu, Y.; Chen, Y. C. Inhibitory Effects of the Four Main Theaflavin Derivatives Found in Black Tea on Ovarian Cancer Cells. Anticancer Res. 2016, 36, 643-651.

(20) Kobayashi, M.; Ichitani, M.; Suzuki, Y.; Unno, T.; Sugawara, T.; Yamahira, T.; Kato, M.; Takihara, T.; Sagesaka, Y.; Kakuda, T. BlackTea Polyphenols Suppress Postprandial Hypertriacylglycerolemia by Suppressing Lymphatic Transport of Dietary Fat in Rats. J. Agric. Food Chem. 2009, 57, 7131-7136.

(21) Pan, M. H.; Liang, Y. C.; Lin, S. Y.; Zhu, N. Q.; Ho, C. T.; Lin, J. K. Induction of Apoptosis by the Oolong Tea Polyphenol Theasinensin A through Cytochrome $\mathrm{C}$ Release and Activation of Caspase-9 and Caspase-3 in Human U937 Cells. J. Agric. Food Chem. 2000, 48, 6337-6346.

(22) Gali, H.; Perchellet, E.; Gao, X.; Karchesy, J.; Perchellet, J. Comparison of the Inhibitory Effects of Monomeric, Dimeric, and Trimeric Procyanidins on the Biochemical Markers of Skin Tumor Promotion in Mouse Epidermis In Vivo. Planta Med. 1994, 60, 235239.

(23) Fan, F. Y.; Shi, M.; Nie, Y.; Zhao, Y.; Ye, J. H.; Liang, Y. R. Differential Behaviors of Tea Catechins Under Thermal Processing: Formation of Non-Enzymatic Oligomers. Food Chem. 2016, 196, 347-354.

(24) He, F.; Pan, Q. H.; Shi, Y.; Zhang, X. T.; Duan, C. Q. Identification of Autoxidation Oligomers of Flavan-3-ols in Model Solutions by HPLC-MS/MS. J. Mass Spectrom. 2009, 44, 633-640.

(25) Davies, A. P.; Goodsall, C.; Cai, Y.; Davis, A. L.; Lewis, J. R.; Wilkins, J.; Wan, X.; Clifford, N.; Powell, C.; Parry, A. Black Tea Dimeric and Oligomeric Pigments-Structures and Formation. In Plant Polyphenols 2, 3rd ed.; Gross, G. G.; Hemingway, R. W.; Yoshida, T., Eds.; Springer: New York,1999; pp 697-724.

(26) Drynan, J. W.; Clifford, M. N.; Obuchowicz, J.; Kuhnert, N. The Chemistry of Low Molecular Weight Black Tea Polyphenols. Nat. Prod. Rep. 2010, 27, 417-462.

(27) Zhang, G.; Yang, J.; Cui, D.; Zhao, D.; Benedito, V. A.; Zhao, J. Genome-Wide Analysis and Metabolic Profiling Unveil the Role of Peroxidase CsGPX3 in Theaflavin Production in Black Tea Processing. Food Res. Int. 2020, 137, No. 109677.

(28) Subramanian, N.; Venkatesh, P.; Ganguli, S.; Sinkar, P. Role of Polyphenol Oxidase and Peroxidase in The Generation of Black Tea Theaflavins. J. Agric. Food Chem. 1999, 47, 2571-2578.

(29) Kobayashi, S.; Higashimura, H. Oxidative Polymerization of Phenols Revisited. Prog. Polym. Sci. 2003, 28, 1015-1048.

(30) De Regil, R.; Sandoval, G. Biocatalysis for Biobased Chemicals. Biomolecules 2013, 3, 812-847.

(31) Pourcel, L.; Routaboul, J. M.; Cheynier, V.; Lepiniec, L.; Debeaujon, I. Flavonoid Oxidation in Plants: from Biochemical Properties to Physiological Functions. Trends Plant Sci. 2007, 12, 2936.

(32) Verloop, A. J.; Vincken, J. P.; Gruppen, H. Peroxidase Can Perform the Hydroxylation Step in the "Oxidative Cascade" During Oxidation of Tea Catechins. J. Agric. Food Chem. 2016, 64, 80028009.
(33) Finger, A. In-Vitro Studies on the Effect of Polyphenol Oxidase and Peroxidase on the Formation of Polyphenolic Black Tea Constituents. J. Sci. Food Agric. 1994, 66, 293-305.

(34) Shaji, J.; Lal, M. Nanocarriers for Targeting in Inflammation. Asian J. Pharm. Clin. Res. 2013, 6, 3-12.

(35) Kim, Y. J.; Uyama, H.; Kobayashi, S. Peroxidase-Catalyzed Oxidative Polymerization of Phenol with a Nonionic Polymer Surfactant Template in Water. Macromol. Biosci. 2004, 4, 497-502.

(36) Green, L. C.; Wagner, D. A.; Glogowski, J.; Skipper, P. L.; Wishnok, J. S.; Tannenbaum, S. R. Analysis of Nitrate, Nitrite, and [15N] Nitrate in Biological Fluids. Anal. Biochem. 1982, 126, 131138.

(37) Mosmann, T. Rapid Colorimetric Assay for Cellular Growth and Survival: Application to Proliferation and Cytotoxicity Assays. J. Immunol. Methods 1983, 65, 55-63. 